\title{
PONDOK PESANTREN DAN ISSU JIHAD \\ (Studi Pada Pondok Pesantren \\ Karya Pembangunan Manado)
}

Oleh: Sirajuddin Ismail

\begin{abstract}
Abstrak
This research was conducted in Manado, North Sulawesi. The focus research is Pesantren Karya Pembangunan. This research aims tofind relation between Pesantren and jihad issue. This use qualitative method. Data was collected by using interview and analyzed by qualitative description.

This research indicates that students of this Pesantren equalize understanding of hardness in the form ofradicalism, fundamentalism, terrorism, war, demonstration; and differentiate with understanding of jihad because jihad in Islam has certain regulation that goals to obtain the kindness to human being.
\end{abstract}

Keywords: Pesantren Karya Pembangunan Manado, jihad.

\section{PENDAHULUAN}

$\mathrm{R}$ adikalisme lahir sebagai respon dari situasi ketidakpastian akibat perubahan sosial yang terjadi, disamping diilhami oleh motif religius, sosial politik dan ekonomi. HampirsemuaNegarayang memiliki kelompok Islam radikal berusaha meyakinkan negara Barat bahwa Islam bukan teroris dan pesantren bukan sarang teroris sebab tidak semua tindak kekerasan itu mewakili Islam dan pelaku kekerasan itu tidak semua berasal dari pesantren. Suatu kenyataan yang harus dihadapi oleh Barat, bahwa Islam memiliki nilai luhur yang bertentangan dengan terorisme, karena terorisme adalah kejahatan terhadap kemanusaan dan peradaban serta menimbulkan ancaman terhadap keamanan negara. Oleh sebab itu kewajiban bagi umat Islam untuk 
sama dengan agama Yahudi sebagai agama teroris, terorisme tidak memiliki tempat di dalam ajaran Islam, sebab Islam adalah agama rahmatan lil alamin. Memang dalam kurikulum pendidikan agama terutama kurikulum kepesantrenan diajarakan tentang jihad dan ajaran jihad tidak sama dengan terorisme, artinya jihad bukan seperti yang terdapat dalam pikiran orang Barat, jihad memiliki norma dan koridor tersendiri yang wajib ditaati oleh umatnya.

Masalah pokok dalam penelitian ini, adalah potensi radikalisme di Pondok Pesantren Karya Pembangunan (PKP) Manado. Dari masalah pokok tersebut secara rinci dirumuskan, apa dan bagaimana Islam dan keberadaan pondok Pesantren Karya Pembangunan. Seperti apa potensi radikalisme yang teradapat dalam kurikulum kepesantrenan, bagaimana pemahaman tentang radikalisme di pesantren PKP dan faktor yang mempengaruhi pemahaman radikalisme tersebut.

Tujuan penelitian ini, secara teknis tujuan penelitian ini terbagi atas dua bagian, yaitu 1) Tujuan Umum, menggambarkan potensi radikalisme yang terdapat di pondok Pesantren Karya Pembangunan di Manado. 2) Tujuan Khusus, menmgambarkan apa dan bagaimana Islam dan keberadaan pondok Pesantren Karya Pembangunan. Seperti apa potensi radikalisme yang teradapat dalam kurikulum kepesantrenan, bagaimana pemahamannya tentang radikalisme di pesantren PKP dan faktor yang mempengaruhi pemahaman radikalisme tersebut.

Sedangkan kegunaan penelitian, diharapkan sebagai bahan masukan bagi penentu kebijakan dalam rangka perencanaan pembangunan terutama pembangunan keagamaan yang berhubungan dengan pondok pesantren yang dicurigai oleh pihak Barat sebagai lembaga yang merupakan sarang terorisme.

\section{PERSFEKTIF TEORI}

Konsep radikalisme. Kewajiban mengamalkan ajaran Islam bagi setiap Muslim merupakan konsekwensi dari pilihan menganut Islam, Al Quran, Hadis dan ijma' Ulama adalah sumber hukum yang menjadi acuan di dalam hidup dan kehidupan sebagai seorang Muslim, yang menurut Rahman (1987:49) diidentikan dengan moral yang terpancardari titik monoteisme dan keadilan sosial. Nata, (Nata, 1997:5) mengemukan, bahwa penegakan cita-cita Islam yang iiakselerasikan pada akhir abad kedua puluh melahirkan keragaman anikulasi keagamaan. Keragaman tersebut meliputi tataran 
pikiran, penghayatan dan sistem Sosial. Keragaman inilah yang memunculkan perbedaan, baik di lingkungan komunitas internal agama Islam sendiri, maupun dalam kaitan dengan kehidupan yang lebih luas.

Landasan terori yang digunakan pada penelitian ini, adalah pendekatan Fungsionalisme. Akar fungsionalisme dapat ditemukan dalam karya Durkheim yang memiliki jejak sangat berarti dalam pemikiran sosiologi dan antropologi kontemporer. Dua prinsip utamanya, adalah a) kekuatan-kekuatan sosial memberi paksaan eksternal pada individu-indidu. b) Individu-indivi ini terorganisir secara hirarkis oleh kekuatankekuatan tersebut. (Troung, 1992: 35) Pendekatan fungsional menekankan pada kekuatan institusional sebagai instrumen yang paling penting dalam menentukan arah kebudayaan. Burger mengemukakan, bahwainstitusi tidak hanyamengatur, membuat regulasi, tetapi jugamelakukan kontrol terhadapperilaku masyarakatnya. (Wuthnow, 1987:41)

Berangkat dari konsep fungsionalisme yang dikemukakan oleh Dukheim, lembaga pendidikan sebagai salah satu institusi sosial memberikan paksaan eksternal kepada anak didiknya untuk ikut dalam apa yang telah dikonstruksi oleh pendidik dan secara otomatis anak didik memproyeksikan untuk masuk dalam lingkaran paedagogik yang telah diatur sedemikian rupa oleh sistem pembelajaran di sekolah. Oleh sebab itu perilaku sosial masyarakat sangat ditentukan oleh niali dominan yang dibangun dalam institusi sosial termasuk lembaga pendidikan.

\section{METODE PENELITIAN}

Sasaran penelitian, adalah Pondok Pesantren Karya Pembangunan di Kota Manado dan penelitian ini mengkaji secara mendalam terhadap dunia empiric dan menggunakan pendekatan kuantitatif dan kualitatif. Tehnik pengumpulan data, data skunder diperoleh melalui kajian pustaka, yaitu melalui buku atau catatan yang berhubungan Islam, Pondok Pesantren Karya Pembanguan. Sedangkan Data Primer diperoleh melalui, a) wawancara mendalam dengan informan, baik informan kunci maupun informan biasa tentang apa dan bagaimana Islam, Pondok pesanteren Pondok Karya Pembangunan. Potensi radikalisme dalam kurikulum pendidikan, pemahaman tentang radikalisme dan faktor yang mempengaruhi pemahaman radikalisme. b) jawaban responden melalui hasil angket yang dilakukan terhadap responden (santri) yang menimba ilmu 


\section{Sirajuddin Ismail}

pengetahuan di pondok pesantren Pondok Karya Pembangunan (PKP).

Data kuantitatif yang diperoleh melalui angketdioleh dengan analisaprosentase sederhana, Sedangkan data kualitatif dilakukan pengolahan data sesuai dengan sifatnya, terutama dari hasil wawancara bebas diolah secara kualitatif sesuai dengan jenis data dan tujuan penelitian. Demikian pula dilakukan pengelompokan data dengan memperhatikan data yang sejenis dan data yang memiliki perbedaan antara satu sama lain. Kemudian diidentifikasi keterkaitan di antara data tersebut, terutama faktor yang menghubungkannya. Interpretasi data dilakukan tanpa mengabaikan data emik dan etik.

\section{TEMUAN LAPANGAN}

Profil Pondok Pesantren Pondok Karya Pembangunan

Pesantren Pondok Karya Pembangunan dikenal pula dengan istilah Pesantren PKP didirikan pada saat menjelang diselenggarakannya Musabaqah Tilawatil Qur'an X di Manado pada tahun 1977, Prof. Dr. H. Mukti Ali sebagai Menteri Agama memiliki ide untuk mendirikan satu sarana monumental untuk kepentingan umat Islam Manado. Wacana ini ditindaklanjuti oleh gubernur Sulawesi Utara (H.V Worang), dengan menyiapkan tanah milik pemerintah untuk tujuan tersebut. Pada awal tahun 1977 dimulailah pembangunan fisik di Kelurahan Kombas kecamatan Molas Kodya Manado. bangunan tersebut dibangun satu gedung aula, 2 lokal asrama, 1 lokal sekolah, dan 1 musala di atas areal tanah seluas $7000 \mathrm{~m} 2$.

Pada Musabaqah Tilaawatil Qur'an tingkat nasional ke X, Juli 1977 Presiden Soeharto meresmikan 2 buah sarana monumental MTQ X tersebut, yaitu Islamic Centre dan Pesantren Karya Pembangunan, di Kota Manado, 16 Januari 1978, PKP ini diresmikan sebagai lembaga pendidikan Islam oleh gubernur kepala daerah tingkat I Sulawesi Utara H.V Worang. Pada tahun 1978/1979 (tahun pertama), dibuka Madrasah Tsanawiyah dengan 22 orang santri putra yang berasal dari utusan daerah tingkat II Se Sulawesi Utara dan dibiayai oleh pemerintahnya masing-masing.

Dalam perkembangannya Pondok Pesantren Karya Pembangunan membentuk yayasan dengan nama Yayasan Karya Islam, Notaris R.H.Hardaseputra,S.H, dengan nomor 50, Tgl 30 Desember 1980. Yayasan tersebut menaungi 3 lembaga masing- 
masing Islamic Center Menado, Masjid Raya Manado dan Pesantren Karya Pembangunan Manado, sedangkan pendiri dan Pembina yayasan ini adalah, 1). Hi.M.Yoesoef Ontowiryo. 2).Drs.Hi.Abdullah Mokoginta. 3).Drs.Ahmad Arbie. 4).Prof .Dr.Abdul Al Johannes Paransa, S.H. 5). Abdul Karim Badjeber, S.H. 6). Drs.Hi. Djainuddin Ahmad. 7). Drs. Sukardi Sugeha.

\section{Visi Dan Misi}

Visi: untuk menciptakan pribadi muslim yang cerdas, yang mampu memahami ajaran Islam dengan benar, disamping dapat memiliki ilmu pengetahuan dan teknologi serta mampu mengamalkan ajaran Islam sejalan dengan perkembangan ilmu pengetahuan dan teknologi, dengan prinsip memilih keseimbangan antara Iptek dan imtaq.

Misi: adalah mengupayakan terciptanya agamawan yang profesional intelektual atau intelektual profesional yang agamawan.Menyiapkan manusia yang muslim yang dapat dan mampu mengembangkan keunggulan potensi daerah untuk turut menciptakan masyarakat yang sejahtera lahir bathin.

Mengembangkan keunggulan fungsi do'a dan zikir dan menumbuhkan keunggulan potensi karya dan pikir, sehingga pola zikir dan pola pikir, terpadu dalam diri mereka sebagai bekal menghadapi segala tantangan.

\section{Tujuan dan Usaha}

Tujuan pendirian Pondok Karya Pembangunan, adalah ;

menciptakan manusia Indonesia seutuhnya, sejahtera lahir batin.

membina dan mengembangkan pendidikan agama Islam dengan membimbing anak didik untuk menjadi manusia yang berkepribadian Islam, yang seimbang antara Imtaq dan Iptek.

memberi bekal kepada santri untuk menjadi orang yang memiliki ilmu agama dan mengamalkannya dalam masyarakat.

menciptakan kader-kader muballigh yang diharapkan agar dapat meneruskan missi dakwah Islam. 


\section{Sirajuddin Ismail}

Untuk mewujudkan tujuan tersebut, maka Pesantren Karya Pembangunan Manado, senantiasa berusaha meningkatkan kualitas yang dituangkan kedalam program pendidikan yang dilaksanakan dalam pesantren, yaitu:

a. Peningkatan pelaksanaan pendidikan dan pengajaran agama dengan sistem dan metode yang lebih efektif, baik yang tercakup dalam kurikulum madrasah, maupun yang ditetapkan dalam pembinaan kepesantrenan.

b. Kepramukaan yang mendidik para santri menghayati kenyataan hidup dalam massy arakat, sehingga menjadi warga negara yang bertanggungjawab terhadap kesejahteraan umat dan bangsa.

c. Seni budaya Islam sebagai manifestasi keagamaan yang bermoral dan bermanfaat untuk menjaga kepribadian dan budi pekerti, sehingga dapat menikmati keindahan hidup beragama.

d. Keterampilan dalam berbagai bidang yang relevan dengan tugas hidupnya di masyarakat, sehingga mampu mandiri, berdaya dan berhasil guna.

e. Olahraga dan kesehatan diintensifkan agar para santri mampu mengamalkan ajaran Islam tentang sehat lahir bathin, sehat jasmani dan rohani sesuai dengan ilmu pengetahuan modern.

\section{Kekhasan Pesantren}

Pendalaman tentang Al-Qur'an dan ilmu-ilmu yang berkaitan dengan Al-Qur'an (Ulumul Qur'aan), mulai dari bacaannya (Qiraatul Qur'an), Tajwidnya (Tartilul Qur'an), terjemahannya dan tafsirannya (Tafsirul Qur'an), sampai pada hafalannya (Tafhidzul Quran) lebih diprioritaskan dalam pesantren, mengaji kitab klasik bahkan dibuka lembaga khusus yang diberi nama 'Madrasah Al- Qur'an".

\section{Sistem Pendidikan.'}

Kurikulum. Pesantren Karya Pembangunan Manado memiliki dua model kurikulum;

\section{a) Kurikulum Madrasah}

Sebagai pendidikan formal madrasah yang ada dalam Pesantren Karya Pembangunan terdiri atas duajenjang, masing-masing madrasah Tsanawiyah dan 
madrasah Aliyah. Kedua tingkatan tersebut di bawah binaan Departemen Agama dalam hal ini Kantor Wilayah Departemen Agama Propinsi Sulawesi Utara.

Pondok Karya Pembangunan Manado melaksanakan kegiatan ekstra kurikulum yang terbagi dalam tigakelompok, yakni:

1). Kelompok Kajian Kitab, yaitu belajar tafsir hadis dan mengkaji kitab kalsik

2). Latihan dakwah dengan menggunakan bahasa Indonesia, Arab dan bahasa Inggris

3). Selain bahasa Arab, Inggris juga diajarkan bahasa Jerman dan Jepang

4). Keterampilan elektronika, komputer, dan bela diri.

\section{b) Kurikulum kepesantrenan.}

Kurikulum kepesantrenan ditetapkan oleh pembina Pesantren Karya Pembangunan disusun bersama dengan pembina lainnya, disesuaikan dengan kondisi santri. Proses pengajaran menggunakan sistem halaqah, bertempat di masjid. Dilaksanakan sesudah magrib dan setelah shalat Subuh, sedangkan materi yang diajarkan, adalah :

1. Tafsir : Jalalain.

2. Hadis : Bulugul Maram.

3. Fihki : Fiqhus Sunnah.

4. Tauhid : Al-Aqidatul Islamiyah.

5. Tasauf : Al-Hikam.

6. Nahwu/Qawaid: Kawakibud Durriyah.

7. Extra kurikuler, pramuka, Palang Merah Remaja, Seni Bela Diri, seni Budaya Islam, Latihan ceramah dengan menggunakan Bahasa Indonesia, Arab dan Inggris.

\section{Sumber Daya Manusia}

Pondok Pesantren Karya Pembangunan pada jenjang pendidikan Tsanawiyah dan Aliyah dibina oleh 28 orang guru/ustadz, 17 orang guru tetap dan 11 orang guru tidak tetap (GTT), 4 orang PNS guru dari Departemen Agama dan 2 orang PNS guru dari diknas. Dua orang tenaga administrasi. 
Sirajuddin Ismail

\section{Santri}

Santri, adalah mereka yang merupakan santri yang mengikuti pelajaran diberbagai jenjang pendidikan (tsanawiyah dan aliyah) itu juga yang mengikuti mengaji pondok (santri), yaitu a) madrasah Tsanawiyah 162 orang (lima kelas) dan Aliyah 18 (dua kelas) b) madrasah Aliyah, 18 orang (dua kelas).

\section{Pesantren dan Issu Jihad}

KHi. Rijali (Pembina) Pesantren Pondok Karya Pembangunan dalam pembelajaran yang berhubungan dengan ilmu tersebut dalam berbagai bentuk secara kaffah sesuai dengan wawasan santri dan sesuai dengan kondisi Indonesia dan dikemukakan dengan semangat iqra' secara konteks yang merupakan salah satu ijtihad. Pembahasan mengenai radikalisme, teroris, bom bunuh diri mengacu pada:

1) Al-Qur'an, al-Maidah (32, 33), al-Hajj (39-40), al-Anfal (60), al-Nisa (29), alBaqarah(195).

2) Hadis Nabi SAW tentang (a) pencegahan menakut-nakuti orang Muslim lainnya. (Riwayat Abu Daud) (b) cegahan mengacungkan senjata tajam kepada sesame Muslim, (riwayat Muslim) (c) cegah melakukan bunuh diri. (riwayat Bukhari Muslim)

3) Kaidah fikih tentang perintah untuk menghindari kerusakan (dharar).

Di dalammenjelaskan kekerasan tersebut, KHi. Rijali menghubungkannyadengan kondisi Indonesia yang marak dengan ujuk rasa dan demonstrasi, yaitu:

1). Tuntunan Islam, bahwa jihad di Indonesia (negaradamai), jihadnyabukan dengan angkat senjata (perang) karena tidak ada lawan yang hams dihadapi dengan kekerasan senjata. Di Indonesia hanya jihad menghadapi kedzaliman, kemungkaran, keterbelakangan dan hanya satu yang dihadapi oleh seorang Muslim dalam hidup dan kehidupannya di Indonesia, yaitu jihad menghadapi hawa nafsu yang pasti terjadi pada setiap diri individu. Hal ini sesuai dengan hadis dari Abi Said al Khudri dan diriwayatkan oleh Imam Muslim, nabi memberikan tuntunan, bahwa siapa sajayang melihat kemungkaran, hendaklah merubah dengan tangannya, kalau tidak rubahlah dengan lisan, kalau tidak rubahlah dengan hati dan merubah kemungkaran dengan hati adalah iman yang paling lemah. 
Konsep tersebut menunjukan bahwa lemah dan dahsyatnya sesuatu dalam diri manusia ditentukan oleh hati (jiwa). Merubah kemungkaran (kedholiman) dengan hati adalah selemah-lemahnya iman, pertanda seseorang tidak memiliki kemampuan menghadapi sesuatu kedholiman (termasuk kategori orang yang dalam keadaan darurat dari segi kemampuan), artinya umat dituntut berjuang sesuai dengan kemampuan yang dimiliki.

2). Sesuai dengan analisa, pendapat yang diperoleh ustadz melalui literatur berupa fatwah Ulama, cendekiawan maupun pendapat para pakar dan pengalaman yang dialami oleh ustadz itu sendiri, antara lain kitab yang menjadi acuan mereka, yaitu a). Fikih al-Sunnah, oleh See Al-Sayyid Sabiq. b). Hasiyat al-Bajuri ala Ibn Qasim al-Gazzi, oleh Ibrahim al-Bajuri. c). Kifayat al-Akhyarfi hill Gayat alIkhtishar, oleh Taqiyal-Din Abi bakr Ibn Muhamad al-Husaini al-Hashani alSyafi'i. Disamping itu KHi. Rijali mengacu pada tulisan Jaih Mubarok, Fatwa Tentang Protes Politis Di Indonesia. Keputusan BM Nahdlatul Ulama (NU), Muktamar Nahdalatul Ulama ke-16 (26-29 Maret 1946) atau 23-26 Rabi' al-Tsani 1365 Di Mojokerto dan Fatwa MUI, artinya mengemukakan tentang ji had dan resiko atau hukumnya disesuaikan dengan kondisi Indonesia. Tiga macam kekerasan yang pernah terjadi di Indonesia dan hukum melakukan jihad dan dikategorikan dalam kelompok fikih siyasah dan juga bisa dikategorikan dalam fikih jinayah, yaitu (1). jihad melawan penjajah. (2). jihad dengan unjuk rasa. (3). jihad berupa terorisme. (Mubarok, 2006: 112)

\section{Jihad melawan penjajah.}

Indonesia, adalah suatu Negara merdeka yang sejak lama lepas dari belenggu penjajahan. Rakyat Indonesia, umat Islam mengkleim bahwa Indonesia adalah Negara Islam yang pernah dikuasai oleh orang kafir, karena sebelumnyapernah dikusai oleh umat Islam, walaupun pernah diduduki oleh penjajah yang kafir. Hukum melawan penjajah seperti itu menurut BM-NU, adalah 1). Perang melawan penjajah dan para kaki tangannya adalah wajib Ain (wajib bagi setiap orang), laki-laki, perempuan maupun anak-aak yang berada ditempat yang dimasuki oleh penjajah dan para pembantunya. 2). Perangi penjajah bagi orang yang tinggal di daerah yang jaraknyakurang dari 94 
Sirajuddin Ismail

Km dari tempat (markas) penjajah, adalah wajib ain. 3). Berperang melawan penjajah bagi orang yang tinggal di daerah yang jarak lebih dari $94 \mathrm{~km}$ dari markas penjajah adalah wajib kifayah. 4). Apabila orang yang tinggal di daerah yang diserang oleh penjajah dan orang-orang yang tinggal di sekitarnya (yang jarak kurang dari $94 \mathrm{~km}$ ) tidak secara kuantitas tidak mampu untuk melawan penjajah, maka orang yang tinggal di daerah diluarnya (lebih dari $94 \mathrm{~km}$ ) wajib membantu. Hal ini merupakan Keputusan MB-NU dalam Muktamar Nahdlatul Ulamake-16,26-29 Maret 1946, Purwokerto). (lihatMasyhur, 197)

Sedangkan dalam resolusi Muktamar Ulama ke-16 terdapat redaksi dan keputusan yang agak berbeda. Perbedaan antara informasi tersebut dengan resolusi Muktamar Ulama ke-16 terletak pada Ketetapan yang keempat, yaitu tentang keharusan membinasakan kaki tangan penjajah atas nama agama Islam.

Keputusan tersebut didasarkan padapendapat ulama yang dikutip dari kitab alBujairimi' ala Fath al-Wahab, Asna al-Mthalib dan Fath al-Qarib. Jarak 94 km sebagai batas wilayah karena dianalogikan dengan jarak perjalanan diperbolehkannya qashar dan jamak shalat wajib. (Sabiq, 1983: 238-241. Albajuri, T.th: 204-205. Abi Bakar, T.th: 141-142) Secara logika kewajiban berperang melawan penjajah tidak dihukumfardu ain bagi yang ada diluar wilayah (lebih dari $94 \mathrm{~km}$ ) karena kewajiban itu akan menyulitkan masyarakat yang bersangkutan dan hal itu dijelaskan pula dalam kitab Rawdhat al-Thalibin.

Konsep perang melawan musuh atau penjajah dibahas oleh ulama dalam kitabkitab fikih pada babjihad (al-jihad) yang seakan dengan kata al-ijtihad yang berarti sungguh-sungguh (al-juhud). Oleh karena itu pembahasan mengenai perang perang melawan musuh dapat dilihat dalam kitab Fikih babjihad dan orang yang meninggal dalam perang melawan musuh dihukum syahid. Tetapi menurut KHi.Rijali tidak ada mati syahid di Indonesia yang ada mati ma 'rifat karena mati atas kemenangannya melawan hawa nafsu, sebab mati bagi orang sufi, adalah mati syariat, tarrekat, hakikat dan ma'rifat. Oleh sebab itu perang paling dahsyat yang dihadapi oleh 
masyarakat Indonesia tidak ada kecuali perang menghadapi hawa nafsu yang dihadapai oleh setiap pribadi Muslim, sesuai dengan pernyataan nabi Muhamad sesusai perang Badar, bahwa perang yang paling dahsyat adalah perang melawan hawa nafsu. (AsSunnah)

\section{Jihad dengan Unjuk Rasa.}

Unjuk rasa pada batas tertentu sering dipandang sama dengan demonstrasi (demo), akan tetapi nampaknya makna demonstrasi lebih universal. Sebab unjuk rasa sangat terkait dengan persoalan politik, sedangkan demonstrasi disamping persoalan politik juga mencakup persoalan sosial, antara lain seperti ekonomi dan keamanan.

Kenyataan sekarang unjuk rasa, adalah pengarahan massa sebagai simbol kekuatan yang dilakukan untuk memperotes sesuatu yang dipandang zhalim (ketidak adilan). Dalam sejarah politik Indonesia Soekarno, Suharto dan KHi. Abdurrahman Wahid terpaksa meletakan jabatannya akibat dari njuk rasa yang dilakukan oleh mahasiswa yang didukung oleh masyarakat. Fenomena demikian juga terjadi demonstrasi yang dilakukan oleh masyarakat, antara lain buruh diperusahan di Jawa, mahasiswa di berbagai sekolah tinggi karena ketimpangan yang dilakukan oleh elit sosial terhadap mereka. Tetapi elit sosial KHi.Rijali sebagai pembina pesantren Pondok Karya Pembangunan berpendapat bahwa unjuk rasa dan demonstrasi adalah sama, memiliki tujuan yang sama menuntut pengentasan ketimpangan dalam masyarakat.

KHi.Rijali menyamakan semua tidakan kekerasan termasuk demnstrasi dan ujuk rasa, sehingga dalam menetapkan hukum juga sama, disamping mengacu dari hadis riwayat Muslim tersebut, kitabfikih, kitabIhya' Ulumal-Din (Keputusan BM-NU), bahwa demonstrasi atau unjuk rasa untuk menegakan amar ma'ruf nahi mungkar, memperjuangkan kebenaran dan untuk menegakkan kebenaran hukumnyaboleh (mubah) dengan syarat, Pertama, unjuk rasa tidak disertai dengan pengrusakan fasilitas umum, baik milik pemerintah maupun milik pribadi dalam masyarakat. Kedua, tidak mendatangkan bahaya baik pelaku maupun pihak lain (masyarakat umum), melakukannya dengan mengganggu pengguna jalan lain, menggunakan kendaraan yang bermuatan berlebih-lebihan, duduk sampai diatap mobil akan berakibat merusak mobil dan jatuh. Ketiga, sebagai alternatif terakhir, karenajalan lain seperti musyawarah, lobi mengalami 


\section{Sirajuddin Ismail}

jalan buntu, dalam keadaan terpaksa (al-hajat atau al-dharurat) karena terkadang unjuk rasa berakhir dengan musyawarah yang menguntungkan semua pihak. Keempat, apabila ditujukan terhadap pemerintah hanya boleh dilakukan dengan dua cara, yaitu 1). Al-ta'n/(menyampaikan penjelasan tentang keadilan atau penyimpangan yang harus ditangani oleh pemerintah). 2). Al-wa'zhu (penyampaian nasehat agar pemerintah mematuhi peraturan demi kemaslahatan umum).

\section{Jihad dengan Terorisme.}

KHi. Rijali dalam membicarakan masalah terorisme, membedakan antara terorismen dengan a/-hirabat, jihad dan pendapatnya seirama dengan fatwa MUI yang dikenal dengan ijma' Ulama komisi Fatwa Se-Indonesia, antara lain mengemukakan tentang terorisme. diputuskan pada 16 Desember 2003 (22 Syawal $1424 \mathrm{H})$. Ulama sepakat bahwa belum ada pengertian terorisme, Tetapi men unit MUI terorisme secara umum, adalah kejahatan terhadap kemanusiaan dan peradaban yang menimbulkan ancaman serius terhadap kedaulatan Negara, bahaya terhadap keamanan, kesejahteraan dan perdamaian dunia. (MUI, 16 Desember 2003)

Setiap kekerasan memiliki cirri tersendiri yang membedakannya dengan yang lain, maka cirri terorisme, adalah a) kejahatan yang terorganisir dengan baik. b) bersifat transnasional dan termasuk kejahatan luarbiasa c) tidak membeda-bedakan sasaran.

\section{a) Terorisme dan al-I lirabat.}

Akar dari terorisme, adalah hirabat, akan tetapi antara teroris dan hirabat memiliki perbedaan yang mendasar, karena teroris merupakan kejahatan kemanusiaan, sedangkan hirabat, adalah kejahatan financial (maliyat). (A.Djalil, 1996: 86-89)

Al-hirabat dalam fikih jinayat selalu dihubungkan dengan surat al Maidah 33. Akan tetapi ulama berbeda pendapat tentang al-hirabat dalam ayat tersebut, yaitu 1) al-hirabat berkenaan dengan dengan orang musyrik yang sudah terikat perjanjian dengan Nabi Muhamad SAW, melakukan pembatalan perjanjian dan melakukan perampokan dan melakukan kerusakan di bumi. 2) al-hirabat berkenaan dengan orang Muslim yang murtad. 3) al-hirabat berkenaan dengan orang Muslim yang melakukan perampokan harta orang lain. 4) al-hirabat menurut mazhab Maliki, yaitu menakut-nakuti orang difasilitas umum baik dengan tujuan untuk memperoleh harta maupun tujuan lain. (Audah, 1996:638-640) 
Kerangka tersebut menunjukan, bahwa dengan memperhatikan ciri terorisme dan ijtihad ulama tentang pengertian al-hirabat secara konteks maka pengertian yang paling dekat dengan terorisme, adalah pengertian al-hirabat yang dianut oleh mazhab Maliki. oleh karena itu pelaku atau al-muharib, adalah orang yang mengangkat senjata melawan orang banyak dengan cara menakut-nakuti mereka. Pendapat mereka diperkuat oleh sal ah satu hadis, yaitu barangsiapa yang mengangkat senjata melawan orang banyak dan menakut-nakuti mereka, maka tidak masuk umat kami. (Hadis Muslim, t.th: 55)

\section{b) Terorisme dan jihad.}

Masyarakat kita selalu menghubungkan terorisme dengan jihad, yang sebenarnya keduanya memiliki perbedaan, teroris telah dikemukakan, tetapi jihad memiliki dua pengertian, yaitu (1)jihadal-qital ataual-harb, yaituberupayasecaramaksimal dan bersedia menanggung resiko di dalam perang, termasuk menahan seragan musuh. (2) upaya secara optimal dan berkelanjutan untuk mempertahankan dan meninggikan agama Allah.

Oleh sebab itu perbedaan antara keduanya dapat dilihat atas sifat, tujuan dan metode kekerasan tersebut, yaitu:

Sifat $\quad=$ Terorisme, merusak dan anarkis (al-ifsad wa al-fawdha).

Jihad, perbaikan (al-ishlah) sekalipun dilakukan dengan perang.

Tujuan $=$ Terorisme, menciptkan rasa takut dan menghancurkan pihak lain .

Jihad, menegakan agama Allah atau membela pihak yang dholimi.

Metode $=$ Terorisme, dilakukan tanpa aturan dan sasaran tanpa batas.

Jihad, dilakukan dengan mengikuti aturan syari'at dengan sasaran musuh yangjelas.

\section{Bom bunuhdiri.}

Masyarakat Islam Indonesia ada yang menganggap bahwa bom bunuh diri sama dengan jihad, tetapi secara teks dan konteks memiliki perbedaan. Secara teks jihat, adalah syahid (al-istisyhad), bunuh diri (qatl al-nafs), secara konteks KHi.Rijali 


\section{Sirajuddin Ismail}

membedakan bom bunuh diri dengan syahid (dalam hal ini seirama dengan fatwah MUI), yaitu:

Tujuan = Bom bunuh diri, dilakukan untuk kepentingan diri sendiri, sedangkan Syahid, untuk kepentingan agama dan umat.

Sikap = Bom bunuh diri, bersikap pesimis pada diri dan putus asa atas ketentuan Allah. Sedangkan syahid, bersikap optimis dan tujuannya untuk mencari keridhaan Allah.

Hukum = Bom bunuh diri, hukumnya haram kerena tindakan keputusasaan dan mencelakan diri sendiri, baik dilakukan di daerah damai maupun di daerah perang, sedangkan syahid, hukumnya mubah (boleh).

Oleh karena itu MUI menetapkan bahwa hukum melakukan teror adalah haram, baik dilakukan orang perorang, kelompok, maupun negara, sedangkan hukum melakukan jihad, adalah wajib.

Faktor yang mempengaruhi timbulnya pemahaman radikalisme dalam masyarakat, menurut informan, adalah akibat dari formulasi dari ketidakpuasan seseorang atau sekelompok orang terhadap situasi dan kondisi dalam masyarakat, yaitu 1) lahir ditengah masyarakat (Islam) baik nasional maupun internasional dituduh oleh negara barat terutama Amerika sebagai teroris, ditambah dengan keyakinan bahwa terdapat konspirasi untuk menghancurkan moral umat Islam melalui buday a barat yang sekuler dan dianggap mencemari otensitas masyarakat dan ajaran Islam, maka timbul upaya tandingan, antipati umat Islam (oknum) yang radikal terhadap Barat (Amerika) dengan berbagai cara untuk mencapai tujuannya, antara lain seperti bom bunuh diri. 2). Orang tidak memiliki ilmu pengetahuan agama dan wawasan yang memadai. 3). Mereka berasal dari masyarakat yang dihimpit oleh persoalan sosial ekonomi, akibat dari pengangguran atau ketidak ketersediaan lapangan kerja, artinya mereka yang secara sosial ekonomi termasuk masyarakat marginal.

Kerangkatersebutmenunjukan, bahwa kondisi itulah yang mempengaruhi psikologi relasi sosial mereka yang menyebkan terjadinya kekecewaan dan frustrasi. kehadirannya dalam radikalis, seakan-akan sebagai penawar bagi kondisi kemarginalan dan fustrasi mereka. 


\section{V.PENUTUP}

\section{Kesimpulan.}

Di dunia pesantren terutama di pondok Pesantren Pondok Karya Pembangunan tidak ditemukan potensi dan mengenal radikalisme. Merekabelajar masalah kekerasan yang mereka kenal dengan istilah jihad, karena itu merupakan salah satu pembahas dalam masalah fikih.

Santri dari Pondok Karya Pembangunan menyamakan pengertian kekerasan berupa radikalisme, fundamental, teroris, perang, demonstrasi dan ujuk rasa dan membedakannya dengan pengertian jihad, karena jihat adalah berjuang dalam Islam memiliki tata aturan tersendiri dalam Islam, yang tujuan untuk memperoleh kemaslahatan.

Di pesantren, persfektif kekerasan dalam berbagai istilah diterangkan sebagi contoh dan merupakan bahan komparasi bagi ustadz ketika membahas tentang jihad. Oleh sebab itu para santri mengenal berbagai istilah kekerasan baik dalam istilah agama maupun istilah umum tetapi mereka tidak tidak aplikasikan dalam hidup dan kehidupan, karena sikap seperti itu adalah prilaku haram yang bertentangan dengan Syariat Islam.

Terjadinya perbedaan asumsi para santri tentang kekerasan, disebabkan karena ustadz kurang memberikan penjelasan dan membedakan mana yang disebut jihad dan mana yang bukan. Atau wawasan murid yang belum bisa menjangkau tentang masalah yang berhubungan dengan kekerasan, sehingga ada yang membolehkan memerangi orang yang tidak seagama dengan mereka.

\section{Rekomendasi.}

Hendaknya para ustadz di pesantren dan para dai memiliki pengetahuan dan wawasan yang luas tentang masalah jihad dan kekerasan dengan berbagi istilah yang terjadi dalam masyarakat, sehingga bisa menjelaskan secara kaffah tentang masalah jihad dan dikomparasikan dengan peristiwa kekerasan agar santri dan masyarakat tidak keliru memahami masalah jihad. 
Sirajuddin Ismail

\section{DAFTARPUSTAKA}

AL- Bajuri, Ibrahim, Hasifat al-Bajuri ala Ibn Qasim Al-Gazzi. I, Thaha Putra,Semarang. T.th.

Abi Bahar, Taqiyal-Din, Kitayat alAkhyar Hill QayatAl Ikhtishar, I, Thaha Putra, Semarang. T. Th.

A. Djajuli, Fiqh Jinayah, Upaya Menanggulangi Kejahatan dalam Islam,_ Cet. I, PT. Raja Grafindo Persada, Jakarta.

Audah, Abd. Al-Qadin, al-Tasyri' al-Jina'I al- Islam; Muqaraman hi al qanun alwadh'i, jilidll,Mu'assahalRisalah,bairut; 1996.

Antoun, Richard, Memahami Fundamentalisme, (terjemahanMuhammad Shadiq), pustaka Mereka, Surabaya, 2003.

Bamuallim, Chaiders, (Ketua Tim Peneliti), Gerakan Islam radikalisme Kontemporer di Indonesia; Front Pembela Islam (FPI) dan Laskar Jihad (FKAWJ), Laporan Penelitian Pusat Bahasa dan Budaya JAJN Jakarta, kerjasama JAJN Syariat Hidayah Jakarta dengan Pemerintah Provinsi DKI Jakarta, Jakarta 2001.

Burger dalam Robert Wuthnow, Cultural Analysis. Routledge. London and Yewyork.

Fazlurrahman, dalam Dr, Hi. Syamsuddin, MA, Sinergi Madrasah dan Pondok Pesantren suatu Konsep Pengembangan Madrasah, Departemen Agama RI. Direktorat Jenderal Kelembagaan Agama RI. Jakarta, 2004.

Ibn Muhammad al-Jagharah, Abu Hamid Muhammad, Ihya Ulum al-Din, Thaha Putra, Semarang. T.Th

Imam Muslim, Shahih Muslim, jilid I Bandung; t.th.

Masyhuri, Abdul Azis H, Masalah Keagamaan Hasil Muktamar dan Munas Ulama Nalidlatul Ulama, PP Rabithah Ma'ahidil Islamiyah, Dinamika Press, Surabaya. 1977.

Mubarak, Jaihdah dalam Dr. Phil Kamaruddin Amin, MA, Quo Vadis Islamic Studies in Indonesia. 